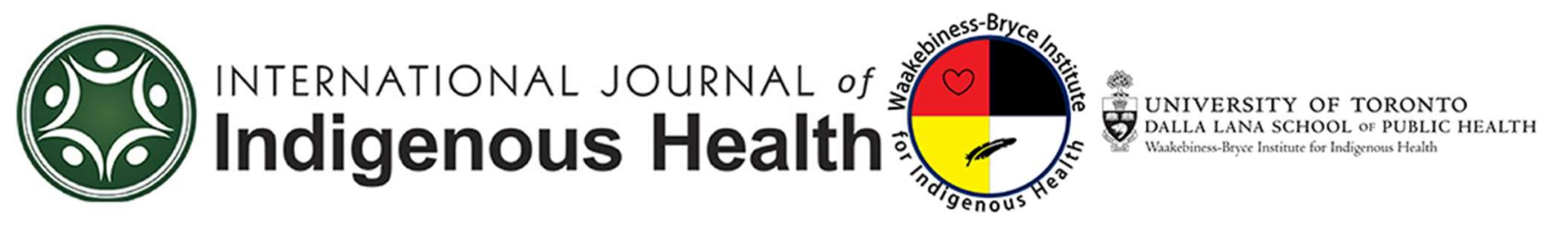

Volume 13

Issue 2. Death and Dying

Article 2

DOI 10.18357/ijih.v13i2.29749

December 2018

\title{
Toku toa, he toa rangatira: A qualitative investigation of New Zealand Māori end-of- life care customs
}

Tess Moeke-Maxwell, Dr.

Te Ārai Palliative Care and End of Life Research Group, School of Nursing, University of Auckland. t-moeke-maxwell@auckland.ac.nz

Rawiri Wharemate,

Te Ārai Palliative Care and End of Life Research Group, School of Nursing, University of Auckland.

r.wharemate@auckland.ac.nz

Stella Black,

Te Ārai Palliative Care and End of Life Research Group, School of Nursing, University of Auckland. stella.black@auckland.ac.nz

Kathleen Mason,

Te Ārai Palliative Care and End of Life Research Group, School of Nursing, University of Auckland.

k.mason@auckland.ac.nz

Janine Wiles, Associate Professor.

Social and Community Health, University of Auckland.

j.wiles@auckland.ac.nz

Merryn Gott, Professor.

Te Ārai Palliative Care and End of Life Research Group, School of Nursing, University of Auckland. m.gott@auckland.ac.nz

Follow the International Journal of Indigenous Health at:
https://jps.library.utoronto.ca/index.php/ijih/index

\section{Recommended Citation}

Moeke-Maxwell, T., Wharemate, R., Black, S., Mason,K., Wiles,J., Gott, M. (2018). Toku toa, he toa rangatira: A qualitative investigation of New Zealand Māori end-of-life care customs. IJIH13(2), 30-46.

DOI:10.18357/ijih.v13i2.29749 


\title{
Toku toa, he toa rangatira: A qualitative investigation of New Zealand Māori end-of-life care customs
}

\begin{abstract}
Informal end-of-life caregiving will increase over the next 30 years in line with the anticipated increase in older Māori deaths. Of concern, New Zealand's neo-colonial trajectory of loss of lands, cultural disenfranchisement, urban migration, ethnic diversity, global diaspora and changing whānau (family, including extended family) compositions has restricted some Indigenous whānau from retaining their end-of-life care customs. This article reports on a qualitative pilot study on Māori whānau end-of-life care customs undertaken to explore how those care customs contribute towards strengthening whānau resilience and bereavement. Five whānau, including 13 individuals from diverse iwi (tribes), took part in one of six face-to-face interviews. Kaupapa Māori research methods informed the analysis. The findings report a high level of customary caregiving knowledge among older whānau carers as well as a cohesive whānau collective support system for this group. Tribal care customs were handed down via 1) enculturation with tribal principles, processes and practices, 2) observing kaumātua processes and practices, and 3) being chosen and prepared for a specific care role by kaumātua. Younger participants had strong cultural care values but less customary care knowledge. The pilot concluded the need for a larger systematic qualitative study of Māori tikanga (customs) and kawa (guidelines) as well as the development of participant digital stories to support a free online educational resource to increase understanding among whānau, indigenous communities and the health and palliative care sectors.Indigenous suicide, Indigenous suicide prevention; Indigenous mental health; Critical suicidology; Indigenous youth suicide; Decolonizing methodologies; Suicidology; First Nations; Aboriginal; Indigenous health; Social determinants of health.
\end{abstract}

\section{Keywords}

Indigenous end-of-life care, Māori caregiving, palliative care.

\section{Creative Commons Licence (@) $\Theta \Theta \Theta$}

This work is licensed under a Creative Commons Attribution-Noncommercial-No Derivative Works 4.0 License. 


\section{Introduction}

The Indigenous proverb 'toku toa, he toa rangatira' ('my bravery is inherited from the chiefs of my forbears') highlights the cultural and spiritual legacies handed down from Māori tupuna (Māori ancestors) to their descendants to equip them to live and die well. Māori (Indigenous people of New Zealand) comprise 15 per cent of the total population (Statistics New Zealand, 2015) (approximately 4.5 million people). The cultural majority are predominately descendants of white British settlers. For Māori, birth and death are viewed as natural events that occur as part of the human life cycle. However, these ordinary life events are imbibed with extraordinary significance due to the heightened spiritual forces that are activated during these transitionary processes (Moeke-Maxwell \& Nikora, 2019). The preparation of the wairua (spirit) during older age and pre-death has great significance for Indigenous Māori. This is reflected in the pilot study's name, 'Pae Herenga', literally meaning the continuous movement of the spirit from before birth, during the time it inhabits its physical form and toward its journey home to the spirit realm.

End-of-life care, and the preparation of the spirit to leave its bodily form are primary functions of indigenous peoples (Duggleby et al., 2015). One of the great legacies from Māori tupuna is the belief in the spirit; it exists pre-birth before it takes up its home in the physical body and before it withdraws at the time of death whence it returns to the spiritual realm. The idea of the spirit transitioning between the metaphysical and physical realms is a core principle underpinning Māori health philosophy and practice, and by extension, end-of-life care and death care customs.

Pre-colonial caregiving customs involved practical processes and care rituals informed by 'tapu' (sanctity) and were underpinned by kawa (customary rituals) (Ngata, 2005) used by tohunga (priests and priestesses) in the treatment (cure) and comfort of the ill and dying. Chosen healers or people close to the ill or dying provided care in the final days of life (Brown, 1851; Dieffenbach, 1843; Hiroa, 1950). Death, like birth, involved the community. Spiritual processes and spiritual responses were needed to care for the ill and dying and to protect and preserve the community particularly as illness and death were often understood as emanating from spiritual transgressions. Heterogeneous tribes and diverse tribal customs meant there were variances among caregiving, dying and post-death rituals. Commonality prevailed in the belief of atua (gods), the spiritual realm and forces (Brown, 1851; Dieffenbach, 1843; Hiroa, 1950).

Many contemporary whānau (family, including extended family) continue to draw on their ancient cultural principles, processes and practices to care for the ill and dying (Ngata, 2005; Ministry of Health, 2001; Ministry of Social Development, 2008; Moeke-Maxwell, Nikora \& Te Awekotuku, 2013). However, the Te Ârai Palliative Care and End of Life Research Group's Kaumātua (Elders) are concerned that exposure to Western paradigms and urbanisation are influencing a change in traditional care patterns and practices, leading to a decrease in resilience among whānau involved in end-of-life care. They believe these cultural customs are a protective factor that support whānau to be resilient (Moeke-Maxwell, Nikora, \& Te Awekotuku, 2014) and need to be retained. Windle (2011) describes resilience within the end-of-life context as: 
... The process of negotiating, managing and adapting to significant sources of stress or trauma. Assets and resources within the individual, their life and environment facilitate this capacity for adaptation and 'bouncing back' in the face of adversity. Across the life course, the experience of resilience will vary (p. 152).

This article reports on the Pae Herenga pilot study undertaken to investigate Māori whānau endof-life care customs. The researchers are members of the Te Ārai Palliative Care and End of Life Research Group, School of Nursing, University of Auckland. We explored how Māori whānau care customs contribute towards strengthening whānau resilience and bereavement. The impetus for this study comes from the Te Ārai Palliative Care and End of Life Group's Kaumātua advisors (referred to hereafter as 'kaumātua'). Kaumātua prioritised the identification and collection of information about traditional care customs to support whānau carers with the increasing demands of end-of-life care (Giesbrecht, Wolse, Crooks \& Stajduhar, 2013). A further six key factors influenced Kaumātua to advocate for the study. Firstly, recent policy changes in NZ resulted in a shift in end-of-life care provision from the acute medical setting to community settings and placed greater responsibility on whānau to provide care within the home (Gott, Williams \& Moeke-Maxwell, 2014; Ministry of Health, 2017). Secondly, due to new medical treatments and pharmacological improvements aimed at prolonging life, whānau are often required to provide care over long periods of time placing stress on caregivers (Seymour \& Gott, 2011). Thirdly, there is an expected increase in older Māori deaths over the next thirty years, placing a high burden on whānau to provide end-of-life care (McLeod, 2016). A fourth factor concerns the difficulties whānau can have in accessing information about palliative care services and supports, something the Kaumātua recognised compounded the care burden (Kidd et al., 2014). A fifth factor reflected the high financial costs associated with care at end-of-life placing additional stress on whānau to cope at this challenging time (Gott, Williams, \& Moeke-Maxwell, 2014). Finally, current palliative care service delivery (e.g., hospice) is informed by policy and structural developments that draw from a Western understanding of 'a good death' and services may not always be congruent with the aspirations of Māori (Claire, 2005).

\section{Pae Herenga Research Methods}

\section{Pilot Aims}

The pilot aims were to investigate Māori whānau end-of-life care customs and to explore how those care customs contribute towards strengthening resilience and bereavement. The aim was to inform the design of a future larger study on this topic.

\section{Kaupapa Māori Research design (KMR)}

A 'by Māori with Māori' pilot study. A Kaupapa Māori Research (KMR) approach and ethnographic and qualitative research methods informed the study design (Bishop, 1996, 1999; Creswell, 2013; Mayring, 2015; The Pūtaiora Writing Group, 2010). KMR requires Māori involvement at every stage of the research process (The Pūtaiora Writing Group, 2010). A senior Māori researcher (TMM) worked with 
the Kaumātua to identify the research questions, collaborate on the research design and conduct fieldwork. Kaumātua helped to identify potential whānau to be interviewed via their community networks and they recruited participants. They also helped to lead two whānau interviews and contributed to a thematic analysis (Braun \& Clark, 2006) drawing on a KMR (The Pūtaiora Writing Group, 2010; Wiles, Rosenberg \& Kearns, 2005) and social constructivist analysis of the findings (Eketone, 2008). Kaumātua also identified knowledge translation pathways to distribute the research findings.

KMR: qualitative methods. Māori are an aural society. Therefore, a kanohi-ki-te-kanohi (face-to-face) data gathering method was employed to support whānau to tell their end-of-life caregiving stories (Bishop, 2005). This also allowed the researchers to carry out their cultural customs by providing manaaki (support, generosity, care) towards participants through incorporating time for whānaungatanga (relationships), karakia (prayers, chants, incantations), waiata (songs, singing), kai (food) and koha (gifts). Recruitment was via the Māori researcher (TMM) and Kaumātua community networks. Either face-to-face or telephone contact was made to invite the whānau participants into the study. A Letter of Invitation, Consent Form and Information Sheet were given to participants prior to their interview. At the start of each interview the research environment is normally charged with a lot of energy. Therefore, certain customary protocols are invoked (McKlintock, Mellsop, Moeke-Maxwell, \& Merry, 2010) to manage the high levels of energy that occur through the activation of wairua (spirit; spiritual forces; energies) that can occur between the living (researchers and participants) and their respective ancestors.

Each participant group was offered the opportunity to have a formal greeting at the start of their interview; some interviews included the following rituals while other participants requested some parts of this process: mihimihi (formal speeches); karakia, korerorero (talking/discussion), kai and after the interview, karakia, waiata and kai were also used to return the environment back to normal (discharge the high level of spiritual energy activated during the interview).

Koha (gifts) were taken to the interview premises; koha included gifts of food to contribute to the pōwhiri (formal greeting customs/process) and a gift voucher to acknowledge time spent in sharing story.

Whānau participants. Six interviews were conducted with five whānau who took part in a one-off interview, including 13 individuals with multiple caregiving experiences. Whānau represented the iwi (tribe) of Ngāpuhi, Tainui, Ngāti Porou, and Te Arawa. Five interviews took place in Auckland, and one in Rotorua. Three interviews took place at the carer's private home. Two further interviews took place in a work environment, and one in a café.

Participant data. Face-to-face interviews were conducted in English and Te Reo Māori (Māori language) using open-ended questions. Each interview was digitally recorded and transcribed. A third koha included the gift of a summary report. Summary reports are a form of negotiated member checking (Birt et al, 2016) using a Collaborative Story Production (CSP) method (Bishop, 1996; Moeke-Maxwell, Wiles, Black, Williams, \& Gott, 2018). The summary reports summarised key information as shared by the participant whānau. Whānau had an opportunity to take part in the CSP member checking method; 
they could make changes, amend or delete content in their summary report (story) they were not happy with.

\section{Tikanga (customs) and kawa (guidelines)}

\section{Findings}

This section sets out the tikanga and kawa that Māori employed to care for their whānau at endof-life. Care was often reciprocal. For example, the ill person needed to know that things were in place to care for their whānau and iwi after they had gone:

...when she was dying, my mum was dying, she said to me 'the most important gift you kids can give to me is to keep together, be good to each other, accept each other's idiosyncrasies, and make sure that you keep up the mana [status, authority and prestige] of the things of the tupuna.' (Ngawai, daughter).

Depending on their level of health, the ill person was an active participant in their end-of-life journey. They provided instructions on care preferences, helped to organise their funerals. as well as visited ancestral homes and other places of whānau or tribal significance in preparation for their passing. They participated in whānau/tribal meetings, passed on whakapapa (genealogy) knowledge, and named babies before they died. Wise counsel was given to whānau members on how to lead their lives. Rewi commented:

Those two years, all those weekends that we had with each other, it was a time for each and every one of us to really spend quality time with our mum... How it helped her? It helped her like to prepare us; you know how sometimes they say that some of them don't go on really peacefully because there's unfinished business. And our mother, I honestly believe that with every single one of us she brought us up to a point where it was like acceptance.

A range of cultural principles, practices and processes supported whānau to provide end-of-life care, often over long periods of time. For example, karakia, kai rangatira (special foods given to esteemed people such as, sea urchins, crayfish and other favorite food items), kotahitanga (collective decision making processes), wairuatanga (spirituality), whanaungatanga (relationships/sense of connection), and tribal values informed and strengthened caregiving practices.

Whānau were pivotal in supporting the ill person to live longer. They helped them to fulfill their cultural and familial obligations and achieve their end-of-life preferences. Daughter Kuini expressed, "as a whole, our overall care should be one that would in the end bring us back together or hold us together, and bring Mum some satisfaction, so that when she's gone, she would know that we would be okay as a whānau."

Ensuring the ill person's wairua felt peaceful was a priority. Whānau helped the ill person to complete things; for example, it was important for a kuia to complete a book of her tribal whakapapa 
before she died. Companionship was provided 24 hours a day; this enabled the ill person to be listened to as they reflected on their past. Rewi, an older son, commented:

I say this having been involved with a lot of the old people, those are the things that keep them alive at the end of the day, those memories of home, of associations, of tikang $\bar{a}$, of great men and great women who have been influential in their lives... [When you go back and say], 'You remember Granny so and so?' [and they reply] 'Oh that old fella?' and away they go [reminiscing]. So, for us, it's not just bringing back the old memories; but what it is, is almost a rest in peace process really and a levelling of a peaceful wairua for all of $u s \ldots$

\section{Whanaungatanga (relationships and connections)}

Whānau who appeared to have a high level of tikanga and kawa were able to carry out a collective whānau system of care. Whānau members returned home upon hearing news of a life limiting diagnosis. For one person, this meant leaving their Australian home to provide care to an ill mother for two years. Care was sustainable because it utilised the collective strengths and resources (including, financial) of the whole whānau. Rewi expressed that the "observance of tikanga" ensured that "islands within the family" were avoided.

Hui (tribal and whānau gatherings) allowed space for discussion and unified decision-making. The very act of being together and sharing the care responsibility strengthened whānau. Whānau made the most of their time with their loved one before they died, particularly if the person was a prominent figure in their iwi; they knew that "handing over" the deceased to "the people" [tribe] for the tangihanga (customary funeral rituals) would take priority following their death.

\section{Aroha (love, concern, empathy)}

The obligation embedded within the cultural principles, processes, and practices of aroha (love, concern, empathy) ensured whānau protected the dying person before and after death. Irihapeti used a spirit of enquiry with her mother (a gentle way of communicating with her about her needs) to ensure her mana was kept intact and her mauri (life force) was preserved. Maia, a younger female carer, described the empathic care she gave her father-in-law:

...so, at the beginning I had to move in slowly, gain his trust, get to know who I am and then I had to learn about [him] and then we can slowly-and then I find out what he likes, the things that makes him happy, and that's like sports and that. [Dementia] it's like a baby being born, being a child, then being a lady... and then a nana and you're going back down... you end up being a baby again, so you've got to nurture them like when they were a baby. That's how I treated 
him. It got to the stage of him calling me 'Mum', because he knows what I was doing for him is what his mum would do for him.

Aroha strengthened whānau to help the dying person's wairua prepare for its transition; for example, encouraging them to "let go" was thought to help them release their wairua from the physical form. Karakia were offered, and waiata were sung to help the dying process. Encouraging words to support the dying process were also spoken by the young:

[My sister] looked up a couple of times and it was just her mokopuna [grandchild], her grandson; he would be seven or eight and he came in, and he came skipping in, and he said 'Nani's [Grandma's] going to go soon.' [He] came in a little boy, skipped up next to his nan, gave her a kiss. Um, and he went out and he got his mum and he says 'I think you had better come in now. Nan's going'. He said it so innocently, how kiddies do.

\section{Wairuatanga (spirituality)}

Older participants reflected on tribal responses to illness and dying. Kura, an older kuia, said:

Again old age; there was no such thing as sickness; it was never seen as sickness. If it was, it was probably more mākutu [spiritual curses]; i.e. they had done something wrong and we hadn't experienced anything like that [Western idea of sickness]; if it was there it was never talked about.

Participants observed different forms of spirituality including Christianity. Spiritual beliefs and practices fortified the ill person and their whānau. Daughter Kaea, recalled her mother using her faith to control her pain:

When I was at the hospital with her I said, 'oh Mum why don't you just go to sleep?' And she said, 'Jesus suffered', that's all I needed to hear. 'Jesus suffered', that's all she said. I'm crying my eyes out for her. That's what she's like.

Spiritual principles, processes and practices underpinned everything whānau did to help alleviate suffering and maintain the mauri of the ill and dying. Upholding their mana until their spirit successfully transitioned across the ārai (veil) revealed a deeply meaningful cultural obligation. The dying person was never left on their own before or after death as whānau believed that feeling safe and loved would help them to transition. Ngawai reflected on her sister's death, "we were all there, she slipped away, and we were singing, 'Can I have this dance for the rest of my life.' That one: 'I had the last waltz with you,' and of course that's what our dad used to sing."

Spiritual principles guided decision-making processes, end-of-life care practices and post-death care. Rituals were utilised for specific care domains: care of the tinana (body), care of the hinengaro (mind/emotions), care of the wairua, care of the whānau, care of the kaingā (home) and preparation of the post-death setting (marae; ancestral meeting house) where the body would lie in state before burial. 
The gathering and preparing of food and drink, for example, and the preparation and application of rongoā Māori (plant medicines) and holistic care, are all attributable to care of the tinana, but were treated as deeply spiritual practices. Kura reflected on how her ancestors prepared themselves to die:

... our old people, they know when they're going to die, because they're getting messages. They know, and the first visible sign is that they will stop eating. The first thing we do [today] is shove [food] into them don't we? That's the first sign. Absolutely, and doctors too will say "you've got to eat", that's totally against the grain. And they know when they're going to go because the spiritual world are telling them so. It comes in different ways and it's fasting, it's straight out fasting. And what that does... they are clearing the body... that is very, very important as well to be aware of what nature is doing... [rongoā] all helps to clear the passages right through and the fasting clears the tract, the oesophagus - it clears the whole tract so that the [body is cleared].... Our people didn't have that [embalming chemicals] but they went into fasting to clear all of that, to make it a lot easier for their passing and also for their caring. It was a two-way process and so we get back to the manuka [native plant] again; it's one example of rongoa that was burnt to help with all of that.

The dying received tohu (messages from the spiritual realm) through visions, signs or dreams; it was common for them to see deceased relatives. Their dreams brought confidence, comfort and encouragement in times of vulnerability. Intuitiveness increased in the dying person as death drew closer; Irihapeti said "[Mum] was very intuitive with her wairua; she always knew, she had a knowing about her." Intuitiveness also increased in whānau. Spiritual phenomena were viewed as a normal part of living at end-of-life. Irihapeti reflected:

[We] always wanted to know how she was, and asked her 'did she feel like this?

What she wanted? How was your sleep, and why are you dreaming?' She had lots of dreams... She always had dreams... And she often saw those who had already passed on.

Spiritual signs signaled the spirit's transition. However not all spiritual signs were welcome, despite them offering a protective warning. Daughter Moana reflected:

$[W]$ e slept at the house at night... my dad was waiting for my whāngai [adopted] brother to come out of the bush. He came out of the bush and he sat down in the bedroom with my dad in a rocking chair. And I was asleep in the lounge; it must have been about 10 or 11 at night and we heard this almighty thumping on our front door, it nearly broke the door off its hinges. And I got up and my chest was pounding. My brother came running down the hall; we ripped open the door, and there was no one there. When my mother got home... we told her and she goes 'did you invite all of your [deceased] aunties and uncles and did you say 'here he is come and take him when you're ready?' And that's what it was. That was a tohu [sign]. I'd never experienced it before in my life extremely powerful. So, they came knocking and my brother and I both knew what it meant and so we shut the door very quickly because we didn't want 
anyone to come in and take him. We slammed the door shut and I remember going back to bed and my heart pounding because I knew they were coming. And he passed away the next night around that time... Yes it was as if they were coming to say 'we're coming'.

\section{Variations in Māori language, enculturation and care customs}

Participants described variances in care customs highlighting the diversity between, and within, whānau. The majority of interviewees $(n=10)$, had a higher level of te reo Māori (Māori language) and traditional enculturation, in comparison to a smaller group of participants $(n=3)$. The 'traditional' group had either observed their Elders providing end-of-life care or they were nurtured with specific skills by their parents and grandparents who recognised their strengths. In contrast, the second group of less traditional whānau had less language proficiency and less cultural knowledge and end-of-life care experience.

The traditional group often comprised large whānau who were well connected enabling a rich collective of whānau carers, often with assigned 'care' roles. For example, Moana said her role was to liaise with her father, who was a prominent member of his iwi, about manuhiri (visitors) who sought an audience with the chief before he died:

[Before he died] I was weaving the threads, constantly weaving, watching, where's this thread [manuhiri/visitor connection] coming from, is it the right thread? I remember people turning up, expecting to get an audience with my father and someone had brought them, a whanaunga [relative] had brought them, and based on that they were [a public celebrity but someone my father did not know personally], I should give them access to my father. Already I knew 'oh...that's wrong'. I went down to Father and I said to him 'Dad so and so's here'- No, I knew, I knew they wouldn't get access to him; I knew. He taught me that valuable lesson about acting from a position of tika [truth; correctness] pono [honesty; sincerity] and aroha.

The traditional care group had in-depth knowledge of wairuatanga. Spiritual practices were drawn on by elders to reduce physical pain, for example. Karakia and waiata were common practices employed to bring relief from physical suffering. Taking older people to visit a beloved ancestral home or tūrangawaewae (place of significance) was another form of spiritual practice that eased the emotions and settled the wairua, particularly before death.

Gendered care roles were observed among the traditional group. Men tended to carry out the spiritual care rituals. For example, Rewi spoke about how he and his brothers fasted to ensure their karakia were tika (correct); karakia had to be strong enough to support their ill mother through her endof-life journey and death transition. Men were responsible for gathering special foods (kai rangatira) to support hosting manuhiri (guests) who visited the ill person before death and also at tangihanga 
(funerals). Women tended to provide personal and intimate care; they also administered medications and oversaw the domestic care setting.

The 'less traditional' group of carers appeared to have strong cultural values which supported them to undertake care; aroha, manaakitanga, whanaungatanga and rangatiratanga [leadership] were some of the core values identified. These dedicated carers provided the bulk of end-of-life and postdeath care. Typically, care was carried out by a primary carer supported by a spouse, or, one or two siblings. These carers tended to be younger and, to some extent, not as connected to their tribal collectives. As the ill person drew closer to death more whānau members would gather to provide support to the dying person. It was often hard for less connected carers to access support from other family members earlier. Daughter Ana reflected on the disconnection within her own whānau:

Because, Dad as such, he wasn't that close with the whannau. And then on Mum's side of the whānau, well they didn't like Dad in a sense... because Dad married their Queenie and so of course Mum's brother was, he was there, but I just felt like I couldn't talk to [him] either. I don't know, I got in [to] this thing that 'oh well it's just you and me Dad'.

Having whānau support was critical at the end of life. Maia explained:

I asked [my whānau] ... when Dad was in hospital, before I brought him home for those eight days, I begged... 'I need one of you [here], because I don't want to be alone when he goes'. So, I had [name of female relative] with me and then [name of male relative] happened to appear the day he passed away.

Heterogeneous whānau often had different values, leading to problems with planning, decisionmaking and carrying out end-of-life and post-death care. For example, Ngawai reflected on the crosscultural issues her whānau experienced when their sister, who was married to a man from a different cultural background, was nearing the end of her life. Differences in cultural values and personal end-oflife care preferences made it extremely difficult for Ngawai's Māori whānau to care for their dying sister in the way they wanted:

... when she was dying, I asked him [brother in law] if we'd put [sister] in the lounge, 'oh no, I want to sleep by my wife - I've slept with her for the last blah, blah, blah, blah'... and so that made it really difficult. We were squashed up in the corner asleep on the armchair ... It would have created more space; we could have all slept around there with her on the sofas ... it would have been like how we did it with our mum. And our mum was in the middle of the lounge and everybody was there. And then to make matters worse, he would put the TV on when we're singing, even when we were doing the church, he put the TV on. I said, 'do you mind?' like that type of ignorance. As far as the strength, where did the strength come from? If my mum hadn't have taught us well, we could have quite easily been had up for murder.

Furthermore, Ngawai's sister was cremated according to her brother-in-laws wishes, a practice that has traditionally been avoided among Māori until recently. 


\section{Transmission of care customs among whānau with high enculturation}

Care roles and specific tasks were assigned to individuals by their Elders. These roles were based on the individual's status within the whānau, reflecting either a tuākana (older sibling) or tēina (younger sibling) relationship position. They were also based on the individual's strengths, often identified during childhood. Strong tribal and whānau values were drawn on to provide end-of-life care such as aroha, whānaungatanga, manaakitanga, kotahitanga (unity; consensus decision-making), rangatiratanga and wairuatanga. Whānau who appeared to have a high level of knowledge and experience using their traditional end-of-life care customs acquired this mātauranga (indigenous Māori knowledge) in two inter-connected ways; through kaitiakitanga (guardianship/stewardship) and role-modeling.

Kaitiakitanga (guardianship/stewardship) was an important component in the whānau care structure. In terms of social care, the kaitiakitanga role was often informed by the wairua of an individual. The right āhua (character/nature) was needed to do a particular job. For example, providing personal care and companionship, attending to the social aspects of care and spiritual care required people with specific skills. The findings revealed that individuals knew their roles, and each contributed to a 'whole system' of care. The system was collaborative and inclusive of older people, whānau and community, and was informed by wairua forces.

Whānau carers learned about their traditional care customs through observing parents, grandparents and other relatives performing specific care roles within the end-of-life context. Closely related to this was the cultural preparation some individuals received to equip them to undertake a specific care role. This helped them to prepare for the time when they would assume an aspect of care responsibility as part of the collective whānau system. Rewi, who had in-depth knowledge of te reo Māori, tikanga and kawa reflected:

I find that 'whakamarama' is better than saying 'well this is what I know or understand.' Whakamarama is a good korero term because 'marama' means light; it means the moon. So when you korero [talk] there is a communication of light between Te Atua [Creator] and down here. Then you turn and you say 'na reira e karanga hoki te aka matua ki konei.' As a boy, the explanation I was given about this is that there is an umbilical cord or the toto that comes from the heavens that come down ... into Papatūānuku [Earth Mother]. And the umbilical cord, the toto that comes from God down to the earth, feeds all creation. For us the toto is wairua ... we have a literal feeling from [the Creator] to us through the aka matua which is a vine.

\section{Best method for future study}

All participants identified that there is a need for whānau to be supported and culturally resourced to provide end-of-life care, particularly for diverse or smaller whānau. Participants want the health and palliative care sector's knowledge and understanding of traditional care customs to increase to benefit whānau service users. 
Given the sensitive nature of the research subject and the bereaved status of research participants, there was an overwhelming response to collect information using KMR principles employing face-toface interviews. Pae Herenga pilot participants strongly recommended that the digital storytelling method be used to collect qualitative information on traditional caregiving. Just prior to being interviewed, six older participants had successfully participated in a digital storytelling project on endof-life care. The digital storytelling method was thought to be a viable tool for stimulating conversation about end-of-life caregiving experiences for Māori. The best method for conducting a larger Pae Herenga study was discussed by Rewi and his sister Kuini:

Rewi: I think that because it's a very personal journey that [the data collection] needs to be in a home where they're comfortable and they have the power to make the choices about how this whole thing goes.

Kuini: Yes, excellent... Having the digital story up front [is] a good way to focus on the initial story or feelings and then coming back to a discussion like this is actually good [as it] then can give it the depth.

\section{Limitations}

The pilot study was primarily conducted in one large urban North Island city, with one interview being conducted in a smaller urban North Island city. As such, it excluded the experiences and perspectives of rurally based whānau (who may have been more likely to have retained their traditional care customs), whānau residing in urban townships and those living in the South Island.

A further limitation was the lower level of enculturation among three of the 13 interviewees resulting in fewer cultural care experiences to examine. While this was a limitation it helpfully highlighted the importance of inter-generational transference of cultural care knowledge customs for Māori carers.

\section{Concluding comment}

Previous research indicates Indigenous cultural and spiritual customs are protective (Duggleby et al., 2015; Ministry of Health, 2001; Moeke-Maxwell, 2014; Moeke-Maxwell et al., 2013a, 2015). An investigation of traditional Māori care customs was considered critical to gather evidence on the link between resilience and traditional end-of-life care customs, itself an under-researched area. The findings highlight that customary caregiving knowledge strengthened whānau to provide end-of-life care. Traditional holistic end-of-life care customs prepared and fortified whānau to provide care throughout the illness-death-tangihanga trajectory. The depth and level of this cultural care was more likely to be held and practiced by whānau who had received cultural mentoring from their tūpuna and who had a high proficiency in te reo Māori, tikanga and kawa. Whānau with less mātauranga Māori upheld the key principles of care demonstrated in their cultural values but were less supported by extended family, therefore they did not benefit as much from the collective care system. 
The findings further highlight that Māori whānau are heterogeneous, and care customs can vary from iwi to iwi and from whānau to whānau. The impact of neo-colonial forces (loss of lands, 'urban drift,' cultural disenfranchisement, global diaspora, ethnic diversity, changing whānau compositions) and living in te ao hurihuri (the changing world) (Gott et. al, 2015; Moeke-Maxwell, 2016; Moeke-Maxwell et al., 2014; Reid, 2005) affect the ability of whānau to retain their traditional care giving customs.

The pilot findings identified that there are some specific cultural practices that helped to strengthen and guide whānau carers. A larger Kaupapa Māori Research study would undertake a systematic collection of qualitative data on traditional care customs to support the end-of-life caregiving activities of whānau. The development of a free, online educational resource, such as digital stories, could help to strengthen whānau who are increasingly being called upon to provide end-of-life care to meet the growing palliative care demand of older people (Moeke-Maxwell, 2014; Moeke-Maxwell, Nikora, \& Te Awekotuku, 2013a; 2015). Access to cultural care information would help to strengthen carer resilience and care sustainability among diverse carers (Moeke-Maxwell, Nikora, \& Te Awekotuku, 2014) by preserving mātauranga (cultural knowledge) on end-of-life care customs. It is critical that whānau are well supported to care for their ill and dying, particularly when it involves the care and protection of the most vulnerable, the oldest old. Maia, a young woman who cared for her father-in-law, highlights that indigenous end-of-life care is deeply relational and is driven by aroha:

Having Dad, it's made me stronger; it's helped me more [or] just as much as I've helped him. Because of his age, being elderly, us as carers, should look at how much more time they've got left and try and make it the best for them. It should be all about them because you [carers] have your own time once they're passed on, because they're not there for long. There's only one more place they go to after being old, and Dad, he knew his time was coming, and I knew his time was coming. And all I could do was just keep on loving him and being there, not leaving him alone - they don't like being alone. It's a lonely world when you're old.

\section{References}

Birt, L., Scott, S., Cavers, D., Campbell, C. \& Walter, F. (2016). Member checking: A tool to enhance Trustworthiness of merely a nod to validation? Qualitative Health Research 26(13), 1802-1811. https://doi.org/10:10.1177/10497323I6654

Bishop, R. (1996). Collaborative storytelling: meeting indigenous peoples' desires for selfdetermination in research. Paper; Meeting of Indigenous education around the world: workshop papers from the world indigenous people's conference. June. Albuquerque: New Mexico.

Bishop, R. (1999). Kaupapa Māori research: an indigenous approach to creating knowledge. In L. Nikora, \& N. Robertson (Eds.), Māori psychology: Research and practice (pp. 1-6). 
Hamilton, New Zealand: Department of Psychology, University of Waikato.

Bishop, R. (2005). Freeing ourselves from neo-colonial domination in research: A Kaupapa Maori approach to creating knowledge. In N. Denzin \& Y. Lincoln (Eds.), The Sage handbook of qualitative research (3rd ed., pp. 109-239). Thousand Oaks, CA: Sage.

Braun, V. \& Clarke, V. (2006). Using thematic analysis in psychology. Qualitative Research in Psychology, 3(2), 77-10. http://dx.doi.org/10.1191/1478088706qp063oa

Brown, W. (1851). New Zealand and its Aborigine. J. \& D.A. Darling.

Claire, S. (2005). Contemporary perspectives. In M. Schwass (ed.), Last words: Approaches to death in New Zealand's cultures and faiths (pp.41-47). Wellington, New Zealand: Bridgett Williams Books with the Funeral Directors Association of New Zealand.

Creswell, J. W. (2013). Qualitative inquiry and research design: choosing among five approaches (3rd ed). Los Angeles: SAGE Publications.

Dieffenbach, E. (1843). Travels in New Zealand: With contributions to the geography, botany, and natural history of that country (Vol. 2). London: John Murray.

Duggleby, W., Kuchera, S., McLeod, R., Holyoke, P., Scott, T., Holtslander, L., . . Chambers, T. (2015). Indigenous people's experiences at the end of life. Palliative \& Supportive Care, 13, 1721-1733. https://doi.org/10.1017/S147895151500070X

Durie, M. (1994). Whaiora: Māori health development. Auckland, New Zealand: Oxford University Press.

Eketone, A. (2008). Theoretical underpinning of kaupapa Māori directed practice. MAI Review, $1,1-3$.

Giesbrecht, M., Wolse, F., Crooks, V.A., \& Stajduhar, K. (2014). Identifying socioenvironmental factors that facilitate resilience among Canadian palliative family caregivers: A qualitative case study. Palliative and Supportive Care, 12(4), 111. https://doi.org/10.1017/S1478951513001028.

Gott, M., Moeke-Maxwell, T., Williams, L., Black, S., Trussardi, G., Wiles, J., . . Kerse, N. (2015). Te Pakeketanga: living and dying in advanced age--a study protocol. $B M C$ Palliative Care, 14(74), 21. https://doi.org/10.1186/s12904-015-0073-4.

Gott, M., Williams, L., \& Moeke-Maxwell, T. (2014). The paradoxes of 'home' within a palliative care context. In M. Roche, R. Mansvelt, R. Prince, \& A. Gallagher (Eds.), Engaging geographies: Landscapes, lifecourses and mobilities (pp. 137-151). Cambridge: Cambridge University Press.

Hiroa, T. R. (1950). The coming of the Maori. Wellington: Thomas Avery \& Sons.

Kidd, J., Reid, S., Collins, N., Gibbons, V., Black, S., Blundell, R., . . Ahu, H. (2014). Kia mau te kahu whakamaru: Health literacy in palliative care. Wellington, New Zealand: Ministry of Health.

Mayring, P. (2015). Qualitative Content Analysis: Theoretical Background and Procedures Approaches to Qualitative Research in Mathematics Education Springer. 365-380.

McClintock, K., Mellsop, G., Moeke-Maxwell, T., \& Merry, S. (2010). Pōwhiri process in 
mental health research. International Journal of Social Psychiatry, Online, 1-

2. https://doi.org/10.1177/0020764010387067

McLeod, H. (2016).'The need for palliative care in New Zealand. Technical report prepared for the Ministry of Health.

Ministry of Health. (2001). The New Zealand Palliative Care Strategy. Wellington, New Zealand: Author.

Ministry of Health. (2017). Palliative Care Action Plan. Wellington, New Zealand: Author.

Ministry of Social Development. (2008). The New Zealand carers' strategy and five-year action plan 2008. Wellington, New Zealand: Author.

Moeke-Maxwell, T. (2016). He wāhine āwhina: a healing narrative of end of life care. In W. Waiatoki, M. Levy (Eds.) Te manu kai i te mātauranga : indigenous psychology in Aotearoa/New Zealand. Wellington, New Zealand: New Zealand Psychological Association.

Moeke-Maxwell, T., \& Nikora, L.W. (2019). Wairua Manuake - Flight of the Wairua: Māori end of life preparations. Publication pending.

Moeke-Maxwell, T., Nikora, L. W., \& Te Awekotuku, N. (2013). Manaakitanga: Ethical research with Māori who are dying. In M. Agee, T. McIntosh, P. Culbertson, \& C. Makasiale (Eds.), Pacific identities and well-being - Cross-cultural perspectives (pp. 188203). London: Routledge.

Moeke-Maxwell, T., Nikora, L. W., \& Te Awekotuku, N. (2014). End-of-life care and Māori Whānau Resilience. Mai Journal, 3(2), 140-152. Retrieved from: http://www.journal.mai.ac.nz/sites/default/files/MAI_Jrnl_V3_iss2_Maxwell.pdf

Moeke-Maxwell, T., Nikora, L. W., \& Te Awekotuku, N. (2015). Homedeathscapes: Māori endof-life decision-making processes. In M. Kepa, M. McPherson, \& L. Manu'atu (Eds.), Home: Here to stay. Wellington, New Zealand: Huia.

Moeke-Maxwell, T., Wiles, J., Black, S., Williams, L., \& Gott, M. (2018). Collaborative Story Production with bereaved family carers of people who died in advanced age. Qualitative Research Journal - publication pending. 30 June 2018.

Ngata, P. (2005). Death, dying and grief. In M. Schwass (ed.), Last words: Approaches to death in New Zealand's cultures and faiths (pp. 29-41). Wellington: Bridgett Williams Books with the Funeral Directors Association of New Zealand.

Reid, P. (2005). Contemporary perspectives. In M. Schwass (Ed.), Last words: Approaches to death in New Zealand's cultures and faiths (pp. 41-49). Wellington: Bridgett Williams Books with the Funeral Directors Association of New Zealand.

Seymour, J., \& Gott, M. (2011). The challenges of health technology for ageing and dying. In M. Gott, \& C. Ingleton (Eds.), Living with ageing and dying: palliative and end of life care for older people (pp. 42-51). Oxford: Oxford University Press.

Statistics New Zealand. (2015). Major ethnic groups in New Zealand. Retrieved from https://www.stats.govt.nz/infographics/major-ethnic-groups-in-new-zealand 
The Pūtaiora Writing Group. (2010). Guidelines for Māori Research Ethics: A Framework for Researchers and Ethics Committee Members. Auckland, New Zealand: Health Research Council.

Wiles, J.L., Rosenberg, M.W., \& Kearns, R.A. (2005). Narrative analysis as a strategy for understanding interview talk in geographic research. Area, 37, 89-99.

Williams, L., Moeke-Maxwell, T., Kothari, S., Pearson, S., Gott, M., Black, S., \& Hansen, W. (2015). Is digital storytelling ka pai for New Zealand Māori? Using digital storytelling as a method to explore whānau end of life caregiving experiences: a pilot study. $B M J$ supportive \& palliative care, 5(Suppl 1), 23.

Windle, G. (2011). What is resilience? A review and concept analysis. Reviews in Clinical Gerontology, 21, 152-169. https://doi.org/10.1017/S0959259810000420 